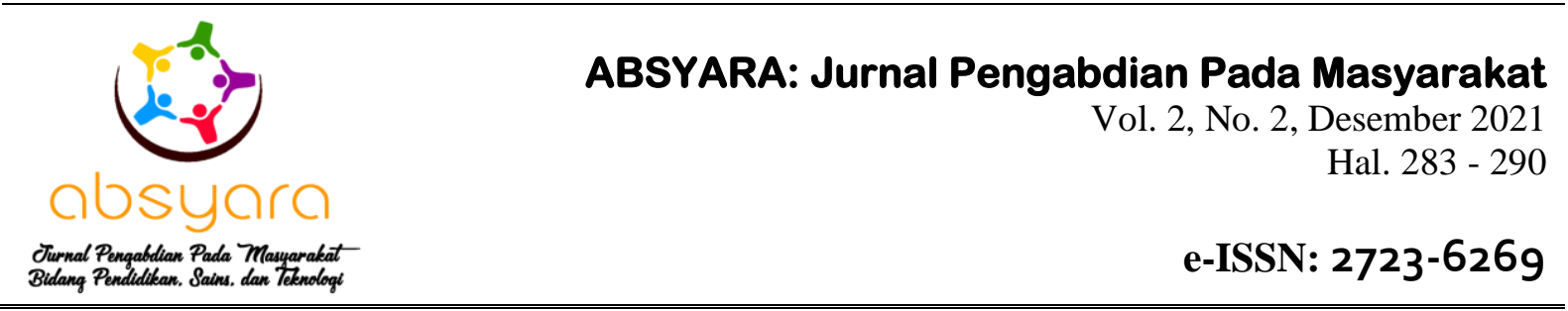

\title{
Penerapan Sistem Monitoring Hidroponik Berbasis Internet of Things (IoT)
}

\author{
Imam Fathurrahman*1, Muhammad Saiful ${ }^{2}$, L. M. Samsu ${ }^{3}$ \\ i.fathurrahman@hamzanwadi.ac.id"1 \\ ${ }^{1}$ Program Studi Teknik Informatika, Fakultas Teknik, Universitas Hamzanwadi \\ 2,3Program Studi Sistem Informasi, Fakultas Teknik, Universitas Hamzanwadi
}

Received: 31 October 2021 Accepted: 14 December 2021 Online Published: 30 December 2021

DOI: 10.29408/ab.v2i2.4219

\begin{abstract}
Abstrak: Hidroponik merupakan metode penanaman tanpa menggunakan media tanah dengan manfaatkan air. Permasalahan terjadi apa bila jumlah air yang digunakan tidak terkontrol. Oleh sebab itu diperlukan sebuah sistem yang mampu mengawasi jumlah air yang digunakan pada sistem penanaman hidroponik. Kegiatan Pengabdian ini bertujuan untuk mengembangkan dan menerapkan sistem monitoring hidroponik berbasis Internet of Things. Kegiatan ini dilakukan oleh mahasiswa yang diikuti oleh beberapa dosen pendamping. Bertujuan untuk membantu mitra dalam mengukur kadar air, suhu, dan pH air pada tanaman hidroponik. mitra unit usaha kegiatan ini salah satunya UKM yang bergerak di bidang budidaya pertanian hidroponik di Science Technology \& Industrial Park (STIPARK) NTB. Kegiatan pengabdian masyarakat ini dilaksanakan selama 4 bulan yang dilakukan secara bertahap dari proses analisa permasalahan mitra, uji coba kepada pengurus STIPARK dan mitra usaha UKM hidroponik maupun masyarakat yang nanti membutuhkan sistem monitoring hidroponik berbasis Internet of Things sehingga informasi dapat diterima secara realtime. Produk ini dapat membantu mitra usaha UKM hidroponik dalam mengetahui tingkat kadar atau nutrisi air, monitoring suhu air dan pH air sehingga bisa membantu petani dalam meningkatkan hasil panen dari budidaya tanaman hidroponik.
\end{abstract}

Kata kunci: Hidroponik; Internet of Things; Sistem Monitoring Berbasis IoT

\begin{abstract}
Hydroponics is a method of planting without using soil media by utilizing water. The problem occurs when the farmer cannot control the water used in hydroponic. Therefore, we need a system to monitor the amount of water used in the hydroponic planting system. This service activity aims to develop and implement a hydroponic monitoring system based on IoT. This activity was carried out by students, followed by several accompanying lecturers. It aims to assist partners in measuring water content, temperature, and water pH in hydroponic plants. One of the business unit partners for this activity is SMEs engaged in hydroponic agricultural cultivation at the Science Technology \& Industrial Park (STIPARK) NTB. This community service activity was held for four months. From the process of analyzing partner problems, they were testing the STIPARK management and hydroponic SME business partners and the community who later needed a hydroponic monitoring system based on the Internet of Things so that information could be received in real-time. This product can help hydroponic SME business partners know the level of water levels or nutrients, monitoring water temperature and water $\mathrm{pH}$ to help farmers increase crop yields from hydroponic cultivation
\end{abstract}

Keywords: Hydroponics; Internet of Things; IoT Based Monitoring System 


\section{PENDAHULUAN}

Science Technology and Industrial Park NTB (STIPark) merupakan UPTD yang berada di bawah naungan Dinas Perindustrian Provinsi NTB. Berawal dari "Techno Park Banyumulek" di bawah pengelolaan LIPI Sampai dengan Tahun 2018, STIPark NTB pertama kali digagas dan dibentuk melalui Bidang Penelitian dan Pengembangan pada awal masa pemerintahan Zulkieflimansyah - Siti Rohmi Djalilah sebagai Gubernur dan Wakil Gubernur dan secara resmi terbentuk dengan Peraturan Gubernur Nomor 45 Tanggal 14 Desember 2018 kemudian diresmikan pada Bulan Januari 2019.

Fungsi STIPark NTB terdiri dari Divisi Inkubasi Bisnis bertujuan untuk menghadirkan start up baru dalam bidang teknologi informasi, permesinan, produk olahan serta industri kreatif melalui Program Pra Inkubasi Bisnis atau Tenant. Target Inkubasi Bisnis STIPark NTB dalam 5 Tahun (2019 - 2023) melahirkan 1000 wirausaha baru dan 100 Tenant. Selain itu, STIPark sendiri hadir sebagai wadah untuk membantu UMKM NTB menyediakan tempat, pelatihan, mencarikan pasar, mencari teknologi yang tepat. Perlu diketahui bahwa dalam mendukung perekonomian mikro dan makro, UMKM merupakan suatu usaha produktif yang perlu di kembangkan (Suci, 2017; Suhartini, dkk., 2021).

Salah satu pelaku usaha binaan mitra STIPARK yaitu budidaya tanaman hidroponik. Teknik budi daya hidroponik adalah teknik yang digunakan dalam menghasilkan produk pertanian yang bebas pestisida, berkualitas, sehat, seragam serta dapat digunakan secara berlanjut (Aksa \& Yanto, 2018; ). Akan tetapi, dalam membudidayakan tanamannya terdapat faktor utama yaitu media tanam dan nutrisi yang dibutuhkan. Media tanamlah yang akan menentukan kualitas dan kuantitas tanaman hidroponik (Sudarmo, 2018). Terdapat lapisan tipis larutan nutrisi pada tanaman hidroponik merupakan hal penting yang diperlukan dalam potensi pengembangan pertanian hidroponik (Maitimu\& Suryanto, 2018). Penggunaan larutan yang dialirkan pada tanaman hidroponik tersebut dapat diatur pada waktu tertentu atau dapat juga dialirkan selama 24 jam. Nutrisi, $\mathrm{pH}$ air, dan suhu merupakan salah satu hal yang penting untuk selalu diperhatikan agar kualitas tanaman menjadi lebih baik (Suharto, dkk., 2016; Tamara, dkk., 2018). Hal ini yang menjadi masalah, karena dibutuhkan ketelitian dalam mengetahui kondisi media tanaman.

Karena itu, perlu adanya proses pengembangan teknologi untuk mengatasi permasalahan yang dialami, salah satu di antaranya adalah teknologi untuk memonitoring kualitas nutrisi dan suhu dari ruang tanam hidroponik secara realtime dalam 24 jam. Pemantauan realtime merupakan pemantauan secara langsung (Gunawan \& Fathurrahman, 2018). Untuk penyelesaian permasalahan mitra tersebut, mahasiswa program studi teknik informatika yang sedang melakukan proses magang beserta dosen berinisiatif membuat pengembangan produk hasil penelitian yang sudah dilakukan dengan membuat produk inovasi untuk membantu menyelesaikan masalah tersebut dalam bentuk pengabdian kepada masyarakat. Alat yang akan dibuat yaitu sebuah sistem monitoring hidroponik berbasis Internet of Things sehingga informasi pada tanaman yang di budidayakan dapat diperoleh secara realtime dipantau melalui smartphone (Umar, dkk., 2020). 


\section{METODE PELAKSANAAN}

\section{Waktu dan Lokasi}

Waktu kegiatan pengabdian ini dilaksanakan pada bulan Juni sampai bulan November 2021 dan tempat pelaksanaan penerapan produk alat inovasi hasil penelitian berada di lokasi Science Techno Industrial Park (STIPARK) NTB.

\section{Prosedur pelaksanaan}

Kegiatan pengembangan produk hasil penelitian yang dilakukan sebagai bentuk pengabdian kepada masyarakat dalam membantu mitra usaha binaan STIPARK NTB dilakukan dengan cara yaitu melakukan analisa permasalahan yang sedang dialami oleh mitra. Kemudian, perencanaan kegiatan yang akan dilakukan terdiri dari pengembangan sistem, uji coba sistem dan sosialisasi ke TIM STIPARK serta dilakukan pengujian sistem atau alat tersebut. Adapun secara umum kegiatan ini dilakukan dengan 4 cara tahap yaitu (Wirasasmita, dkk., 2020):

1. Analisa permasalahan

2. Penentuan bentuk solusi yang ditawarkan

3. Presentasi ke tim STIPARK

4. Pengembangan Produk

5. Pengujian

Kerangka pelaksanaan kegiatan pengabdian kepada masyarakat dalam penerapan produk alat inovasi hasil penelitian ini dapat dilihat pada gambar 1.

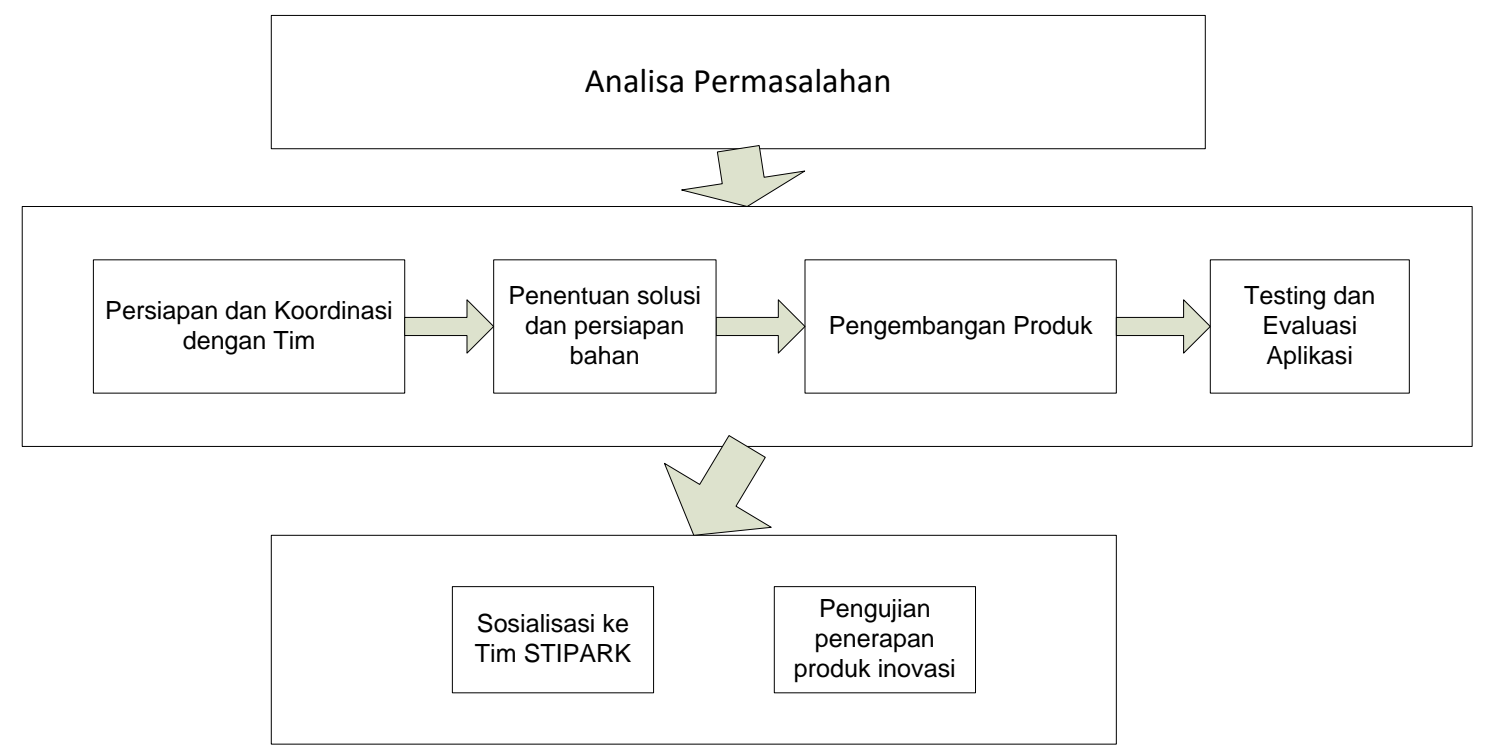

Gambar 1. Kerangka Kerja Pelaksanaan Pengabdian Kepada Masyarakat

\section{HASIL DAN PEMBAHASAN}

\section{HASIL}

1. Analisa Permasalahan

Pada tahap ini tim mahasiswa melakukan proses identifikasi permasalahan yang sering atau dialami oleh pelaku usaha binaan mitra STIPARK yaitu budidaya tanaman hidroponik yaitu salah satunya mengenai nutrisi yang terlalu banyak atau sedikit, penyiraman, suhu 
dan sinar matahari yang dapat mempengaruhi $\mathrm{pH}$ tanaman solusinya harus selalu di monitoring untuk mendapatkan tanaman yang berkualitas baik.

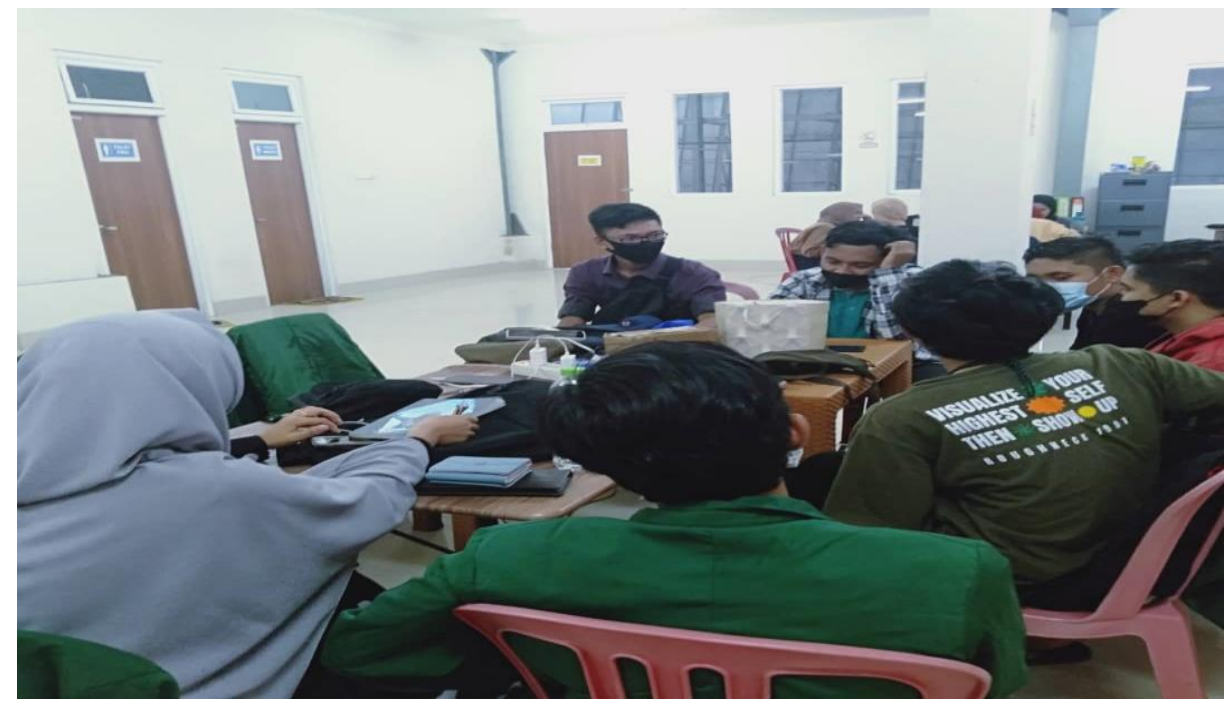

Gambar 2. Mahasiswa melakukan persiapan dan koordinasi dengan tim

2. Penentuan Solusi

Tahap selanjutnya yaitu membuat suatu ide produk inovasi yang bersumber dari produk hasil penelitian untuk bisa di terapkan dalam magang industri di STIPARK NTB. Pelaku mitra usaha ada yang memiliki usaha hidroponik tapi belum maksimal dalam hasil budidaya pertanian hidroponik. Salah satu kegiatan rapat koordinasi dalam penentuan ide produk inovasi di sesuaikan dengan perkembangan teknologi saat ini yaitu menerapkan sebuah sistem monitoring berbasis IoT sehingga dapat di pantau secara realtime dapat terlihat pada gambar 3 .

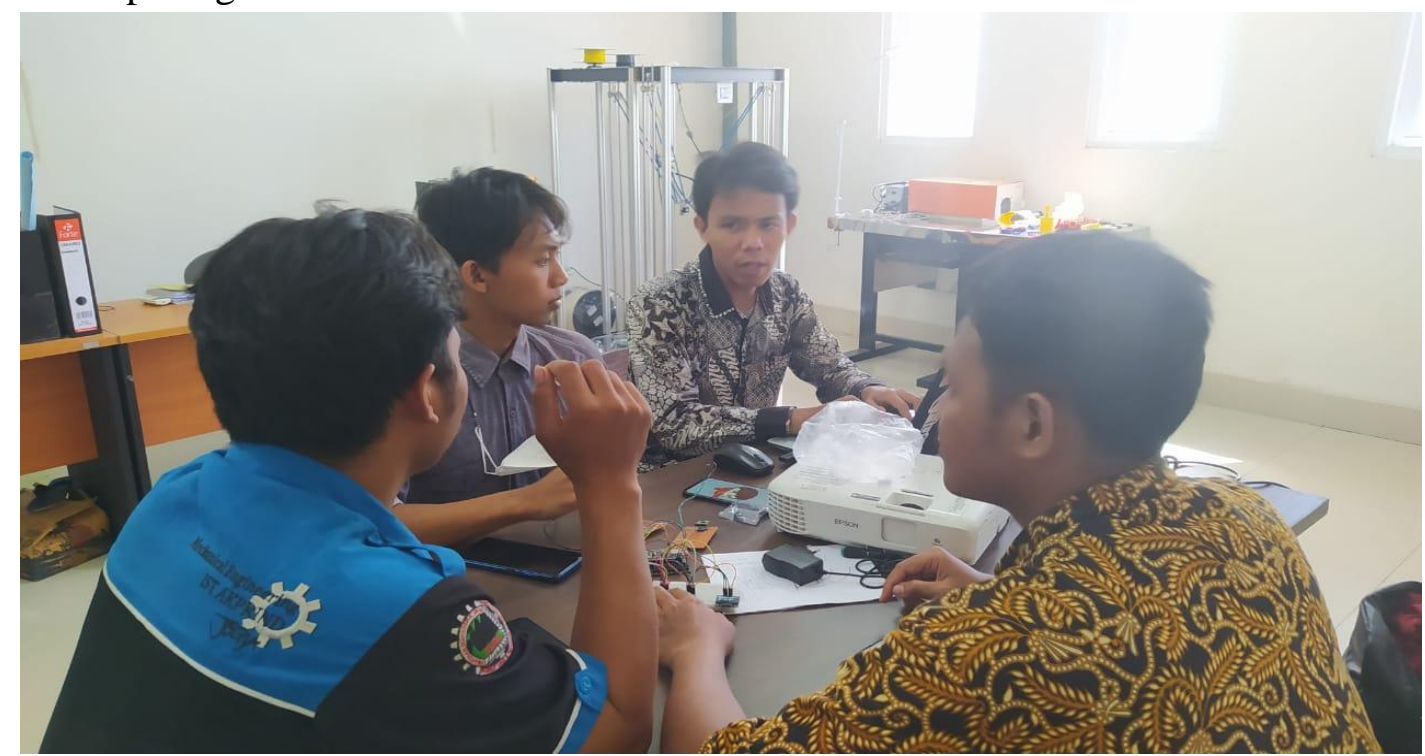

Gambar 3. Bersama tim dalam menentukan solusi dan persiapan bahan yang di perlukan 
3. Presentasi ke TIM STIPARK

Setelah disepakati ide produk inovasi yang akan diterapkan untuk membantu mitra usaha STIPARK kemudian tim magang melakukan presentasi untuk memaksimalkan dalam penyusunan dan perencanaan dalam proses pengembangan dari produk inovasi ini.

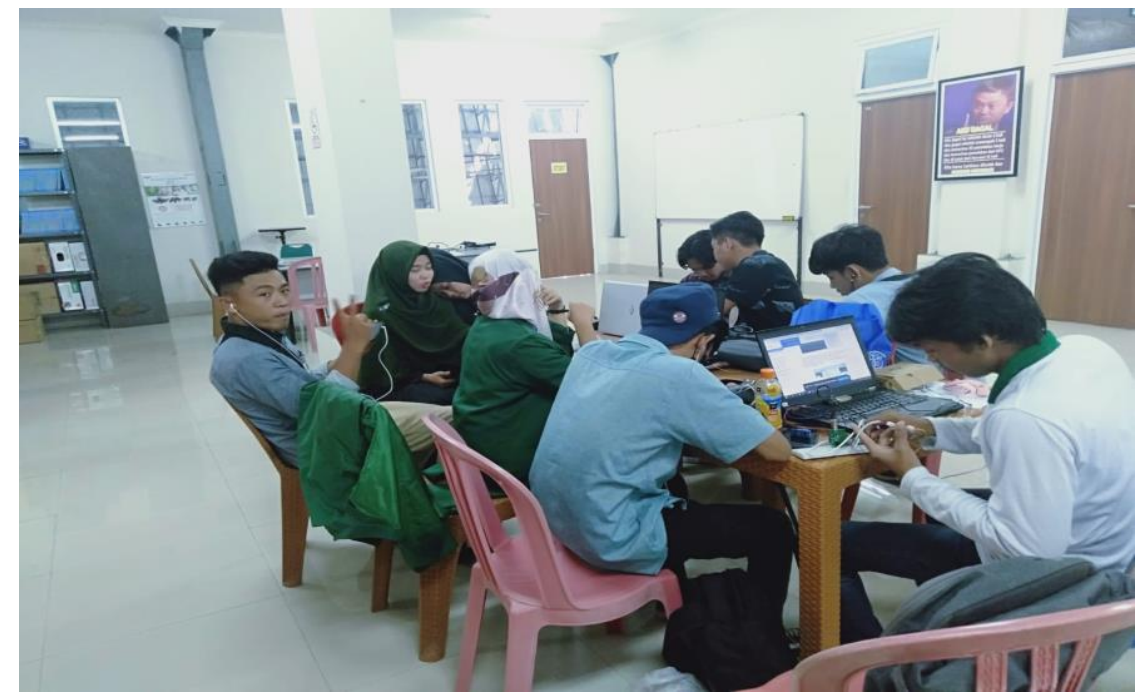

Gambar 4. Mahasiswa magang melakukan persiapan presentasi produk yang di kembangkan

4. Hasil Produk Pengembangan

Terlihat pada gambar 5. Cara kerja dari produk yang di kembangkan adalah saat program sudah dimulai maka semua sensor akan mulai bekerja sesuai dengan fungsinya masingmasing yang terdiri dari sensor suhu, $\mathrm{pH}$ dan nutrisi, yang kemudian data dari sensor tersebut akan diproses oleh modul WIFI NodeMCU ESP32 (Doni \& Rahman, 2020; Dasmen, dkk., 2021). Data yang telah diproses akan disimpan ke cloud server melalui jaringan internet dan akan ditampilkan dalam bentuk grafik pada aplikasi BLYNK pada gambar 7.

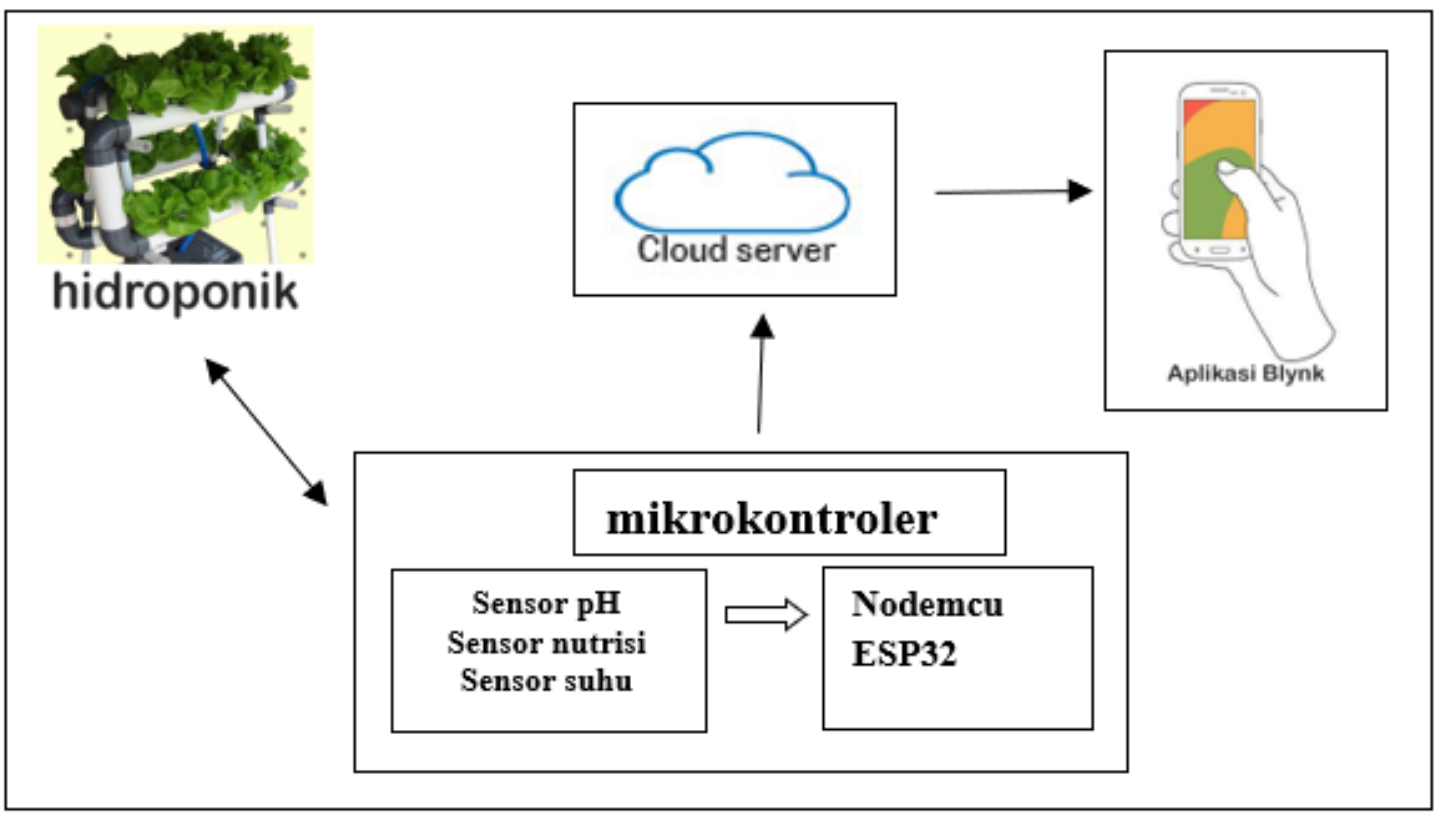

Gambar 5. Alur kerja system monitoring hidroponik 
Berikut dapat dilihat pada gambar 6. Mahasiswa magang melakukan sosialisasi dan pengujian produk yang sudah dikembangkan kepada tim STIPARK kemudian cara penggunaan dari alat tersebut serta informasi yang diberikan oleh monitor sehingga terlihat juga pada gambar 7, pengguna dapat dengan mudah mengetahui kondisi tanah pada tanaman hidroponik dari aplikasi monitoring.

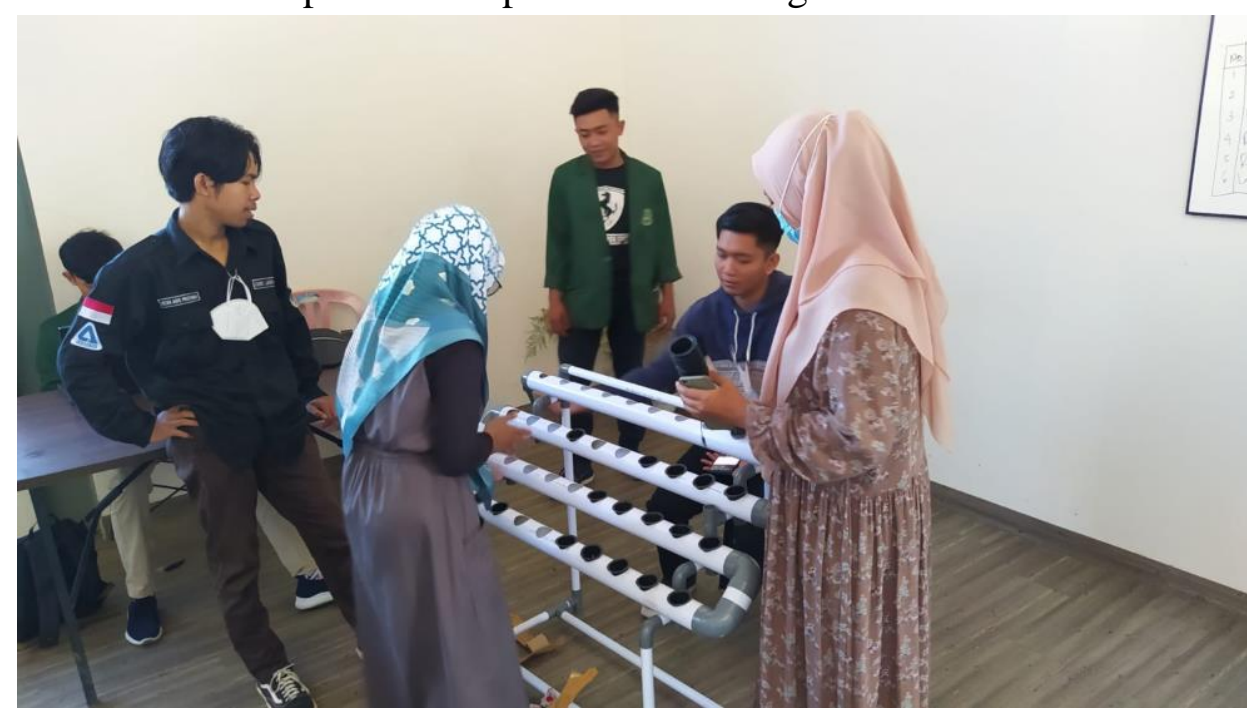

Gambar 6. Sosialisasi dan pengujian produk ke tim STIPARK

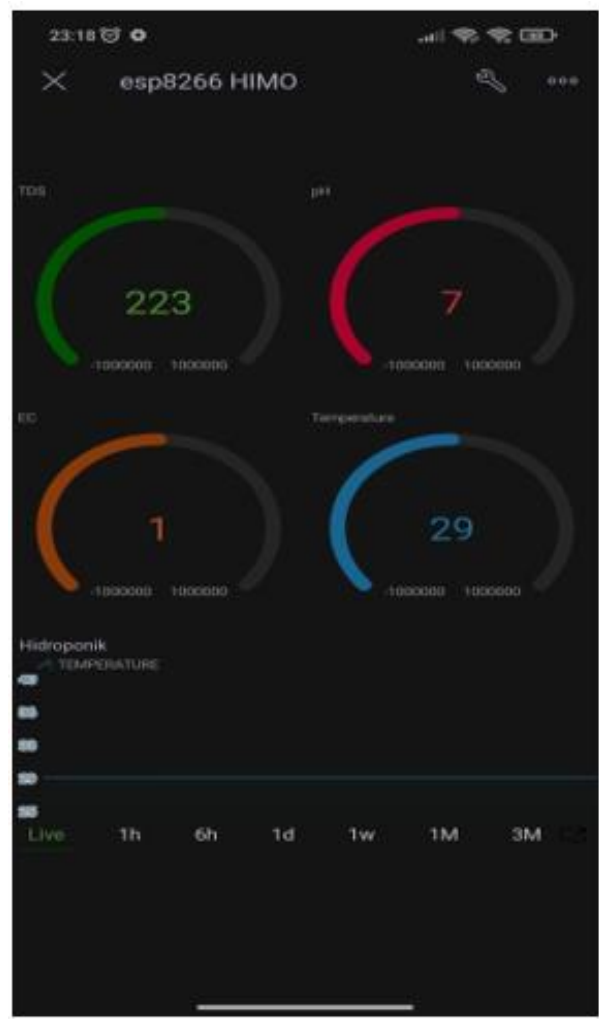

Gambar 7. Hasil Aplikasi Monitoring dan Bentuk Produk Inovasi

Pada gambar 7. Merupakan tampilan pada smartphone menggunakan aplikasi BLYNK dimana data yang ditampilkan salah satunya yaitu kondisi $\mathrm{pH}$ air. 


\section{PEMBAHASAN}

Jika Kondisi nilai $\mathrm{pH}>$ dari $\mathrm{pH}$ normal maka kondisi ini digunakan untuk mengaktifkan pompa yang berfungsi sebagai distribusi nutrisi dari wadah penampung nutrisi ke wadah penampung air. Untuk pengolahan nutrisi menggunakan 2 sensor yang terhubung melalui mikrokontroler, dua sensor tersebut ialah DHT11 yang digunakan untuk mengetahui temperatur dan kelembapan, kemudian sensor TDS yang digunakan untuk mengukur kadar nutrisi tanaman sedangkan Electrical Conductivity (EC) meter digunakan untuk mengukur konduktivitas listrik (Valentin, dkk., 2020). Penerapan teknologi berbasis IoT (Internet of Things) ini tanaman dapat dikontrol dari jarak jauh menggunakan smartphone sehingga dapat meminimalisir intervensi manual dan mendapatkan hidroponik yang cerdas berbasis teknologi.

\section{SIMPULAN}

Hidroponik Monitoring berbasis IoT adalah sistem monitoring budidaya tanaman menggunakan media air berbasis Internet of Things yang memanfaatkan internet untuk mengetahui pertumbuhan dari tanaman sesuai dengan keinginan pengelola. Adanya penanaman teknik hidroponik ini dapat memberikan peluang untuk masyarakat tidak memiliki lahan untuk bercocok tanam dan memudahkan dalam mengontrol tanaman, baik dari segi nutrisi, $\mathrm{pH}$ air, dan suhu. Penggunaannya juga cukup mudah yaitu menancap sensor- sensor yang sudah di sediakan serta mengistal aplikasi BLYNK, sehingga pengelola dapat memantau tanaman dari jarak jauh menggunakan smartphone dan tanaman dapat tumbuh dengan baik menjadi tanaman yang High Quality.

\section{PERNYATAAN PENULIS}

Bahwa penerapan produk inovasi hasil penelitian ini yang digunakan sebagai bentuk untuk pengabdian masyarakat ini belum pernah di terbitkan pada jurnal mana pun.

\section{DAFTAR PUSTAKA}

Aksa, M., \& Yanto, S. (2018). Rekayasa media tanam pada sistem penanaman hidroponik untuk Meningkatkan pertumbuhan tanaman sayuran. Jurnal Pendidikan Teknologi Pertanian, 2(2), 163-168. https://doi.org/10.26858/jptp.v2i2.5172

Dasmen, R. N., Putra, A., Rasmila, R., \& Ibadi, T. (2021). Pelatihan online penerapan teknologi RADIUS pada PT. Taspen (Persero) Palembang. ABSYARA: Jurnal Pengabdian Pada Masyarakat, 2(1), 94-101.

Doni, R., \& Rahman, M. (2020). Sistem Monitoring Tanaman Hidroponik Berbasis Iot (Internet of Thing) Menggunakan Nodemcu ESP8266. J-SAKTI (Jurnal Sains Komputer dan Informatika), 4(2), 516-522.

Gunawan, I., \& Fathurrahman, I. (2018). Prototipe Robot Pemantau Suhu Dalam Zona Kebakaran Gedung Menggunakan Telemetri Jaringan Nirkabel. Infotek: Jurnal Informatika dan Teknologi, 1(2), 107-114.

Maitimu, D. K., \& Suryanto, A. (2018). Pengaruh media tanam dan konsentrasi AB-MIX pada tanaman kubis bunga (Brassica oleraceae var botrytis L.) sistem hidroponik substrat. Jurnal Produksi Tanaman, 6(4).

Suci, Y. R. (2017). Perkembangan UMKM (Usaha mikro kecil dan menengah) di 
Fathurrahman, I., Saiful, M., Samsu, L. M. (2021). Penerapan Sistem Monitoring Hidroponik berbasis Internet of Things (IoT). ABSYARA: Jurnal Pengabdian Pada Masyarakat, 2(2), 283-290. doi:10.29408/ab.v2i2.4219

Indonesia. Jurnal Ilmiah Cano Ekonomos, 6(1), 51-58.

Sudarmo, A. P. (2018). Pemanfaatan Pertanian Secara Hidroponik untuk Mengatasi Keterbatasan Lahan Pertanian di Daerah Perkotaan. In Seminar Nasional Pengabdian Kepada Masyarakat Universitas Terbuka (pp. 1-8).

Suhartini, S., Sudianto, A., Gunawan, I., Permana, B. A. C., Ahmadi, H., Fathurrahman, I., ... \& Nurhidayati, N. (2021). Pembinaan kewirausahaan berbasis teknologi untuk mengembangkan jiwa Technopreneurship. ABSYARA: Jurnal Pengabdian Pada Masyarakat, 2(1), 1-7.

Suharto, Y. B., Suhardiyanto, H., \& Susila, A. D. (2016). Pengembangan Sistem Hidroponik untuk Budidaya Tanaman Kentang (Solanum tuberosum L.). Jurnal Keteknikan Pertanian, 4(2). https://doi.org/10.19028/jtep.04.2.211-218

Tamara, A. P., \& Rahdriawan, M. (2018). Kajian Pelaksanaan Konsep Kampung Tematik di Kampung Hidroponik Kelurahan Tanjung Mas Kota Semarang. Jurnal Wilayah dan Lingkungan, 6(1), 40-57. https://doi.org/10.14710/jwl.6.1.40-57

Umar, U., Adiputra, D., \& Widyantara, H. (2020). Pengembangan Sistem Kendali Kuantitas Air Pada Tanaman Hidroponik Berbasis Internet of Thing (IoT). MULTINETICS, 6(2), 110-116.

Valentin, R. D., Diwangkara, B., Jupriyadi, J., Riskiono, S. D., \& Gusbriana, E. (2020). Alat Uji Kadar Air Pada Buah Kakao Kering Berbasis Mikrokontroler Arduino. Jurnal Teknik Dan Sistem Komputer, 1(1), 28-33.

Wirasasmita, R. H., Arianti, B. D. D., Uska, M. Z., Kholisho, Y. N., \& Wardi, Z. (2020). Edukasi Zero Waste berbasis teknologi informasi. ABSYARA: Jurnal Pengabdian Pada Masyarakat, 1(2), 35-42. 